\title{
Moraxella Commonly Present on the Conjunctiva of Guinea Pigs
}

\author{
BY W. J. RYAN \\ Public Health Laboratory, Exeter
}

(Received 12 August 1963)

\begin{abstract}
SUMMARY
A number of isolates, giving the morphological cultural and biochemical reactions of Moraxella liquefaciens, were obtained from the conjunctiva of healthy guinea pigs. Antigenically they form a single group divisible into two types. No antigenic relationship to known Moraxella species could be demonstrated. The organisms appear to be natural parasites of the guinea pig. No similar organisms were isolated from a small number of wild house mice examined.
\end{abstract}

\section{INTRODUCTION}

The genus Moraxella was originally proposed by Lwoff (1939) and later more fully defined by Henriksen (1952, 1960). It consists of plump, non-motile Gram-negative bacilli, sometimes with a tendency to retain the Gram stain, often coccoid and occurring in pairs but with many pleomorphic forms. The organisms are strict aerobes, oxidase-positive, sensitive to penicillin, do not usually produce acid from carbohydrates, and are often actively proteolytic. Henriksen (1960) recognized four species, i.e. Moraxella lacunata, M. liquefaciens, $\boldsymbol{M}$. non-liquefaciens and $\boldsymbol{M}$. bovis, corresponding respectively to: $(a)$ the Morax-Axenfeld bacillus; $(b)$ Petit's bacillus or M. duplex liquefaciens of Lwoff (1939); (c) the organism first described by Scarlett (1916 $a$ ) and designated M. duplex non-liquefaciens by Lwoff (1939); $(d)$ the organism first isolated by Jones \& Little (1923) from bovine conjunctivitis. The position of $M$. saccharolytica (Flamm, 1956) was regarded as uncertain, and $\boldsymbol{M}$. lwoffi (Audureau, 1940) was excluded from the genus as not conforming to the foregoing description. Henriksen also rejected $M$. lwoffi glucidolytica of Piéchaud, Piéchaud \& Second (1951) on the grounds of its identity with 'Bacterium anitratum' (Schaub \& Hauber, 1948). With one exception, that of $M$. bovis, the natural habitat of all known members of the genus Moraxella has been thought to be the upper respiratory tract or conjunctiva of man. Strains of $M$. lacunata and $M$. liquefaciens have hitherto not been isolated from a source other than man. A proportion of conjunctival swabs taken from apparently healthy guinea pigs in this laboratory yielded an organism with the characters of Moraxella. The properties of selected isolates of this organism were examined and a comparison was made with those of known species of the genus. The present paper is a report of the findings.

Vol. 35, No. 2, was issued 30 July, 1964 


\section{METHODS}

Source of strains

Guinea-pig conjunctival swabs yielded a large number of Moraxella isolates. Of these, eight cultures from three unrelated guinea-pig colonies were retained for more intensive investigation, namely strains E1, E2, E3, T1, L1, L2, L3, L4. All cultures were examined as soon as possible after isolation and were freeze-dried for storage.

Two strains of Moraxella liquefaciens were obtained from the Institut Pasteur, Paris, a typical strain Ref. no. 54.13, and a rough strain Ref. no. A. 183. The following cultures were obtained from the National Collection of Type Cultures, London: M. lacunata NCTC 7986, M. liquefaciens NCTC 7911, and M. bovis NCTC 8561.

\section{Morphology}

Gram's method was used routinely to study the appearance of the organisms. Motility was sought in hanging-drop preparations of young serum broth cultures. Negative staining by the wet Indian ink method (Duguid, 1951) was used for determining the presence of capsules.

\section{Physiology}

Atmospheric conditions. The optimal atmospheric conditions for growth were determined by incubation of inoculated blood agar plates in air, in a candle-jar for increased $\mathrm{CO}_{2}$ tension, and in a McIntosh \& Fildes jar for anaerobiosis (gas: $95 \%$ $\mathrm{H}_{2}+5 \% \mathrm{CO}_{2}$, by vol.).

Temperature. The optimum growth temperature was found by incubation at $37^{\circ}$, $30^{\circ}$, and $25^{\circ}$.

$p H$ value of media. Gradient plates, prepared according to the method of Watson $\&$ Bennett (1957), were used to determine the optimum $\mathrm{pH}$ value. Nutrient agar + serum $(10 \%, v / v)$ was the base used.

Nutritional requirements. Growth requirements were investigated, under optimal atmospheric, temperature and $\mathrm{pH}$ conditions, by using small inocula, with serial subculture when growth occurred, on the following media: Koser's citrate medium (Gillies, 1960); Audureau defined medium (Audureau, 1940); 1\% (w/v) Oxoid peptone water; peptone water medium solidified with $1.5 \%(\mathrm{w} / \mathrm{v})$ Davis powdered agar; peptone water agar enriched with $\mathrm{X}$ and V factors (Stokes, 1960); Lemco nutrient broth; Lemco nutrient agar; Lemco nutrient broth and nutrient agar enriched with $10 \%(\mathrm{v} / \mathrm{v})$ horse serum; Lemco nutrient agar enriched with $10 \%$ $(\mathrm{v} / \mathrm{v})$ horse blood; chocolate agar made from Lemco nutrient agar with $10 \%(\mathrm{v} / \mathrm{v})$ horse blood heated at $70^{\circ}$ for $10-15 \mathrm{~min}$.

Action on carbohydrates. Peptone water enriched with $10 \%(\mathrm{v} / \mathrm{v})$ horse serum and containing $1 \%(\mathrm{w} / \mathrm{v})$ of the appropriate carbohydrate was used with Andrade's indicator. Cultures were incubated for 3 weeks at $37^{\circ}$ before results were recorded as negative.

Oxidase. A few drops of a freshly prepared $1 \%(\mathrm{w} / \mathrm{v})$ solution of tetramethyl$p$-phenylenediamine hydrochloride were poured over a $24 \mathrm{hr}$ culture on blood agar and the development of a purple colour noted.

Phosphatase. The method used was essentially that described by Barber \& Kuper (1951). The organisms were grown on serum agar plates containing $0.01 \%$ 
$(w / v)$ phenolphthalein phosphate. When well grown, the culture was exposed to ammonia vapour.

Catalase. A small amount of growth from nutrient agar or from Loeffler's serum was suspended in one drop of ' 20 vol.' hydrogen peroxide on a glass slide and the production of effervescence observed.

Urease. Christensen's medium (Christensen, 1946) was used. A heavy inoculum was placed on the centre of a slope and incubated $24 \mathrm{hr}$ at $37^{\circ}$.

Nitrate reduction. Strips of filter paper impregnated with potassium nitrate were laid across the surface of blood agar plates and inoculations made by the stab method (Cook, 1950). Browning of the medium around the inoculum indicated reduction of nitrate. Readings were made after incubation for 24 and $48 \mathrm{hr}$.

Egg-yolk opacity. Organisms were grown on serum agar plates containing $10 \%$ (v/v) egg-yolk saline. The egg-yolk saline was prepared by emulsifying the yolk of one egg in $250 \mathrm{ml}$. physiological saline and sterilized by Seitz filtration. Readings were taken after $48 \mathrm{hr}$ incubation.

Indole. Organisms were grown for $48 \mathrm{hr}$ at $37^{\circ}$ in serum peptone water. Ehrlich's reagent was used to test for indole production after extraction of culture with ether.

Serum liquefaction. Liquefaction of coagulated serum was tested on Loeffler's serum slopes. Readings were taken after 24 and $48 \mathrm{hr}$ incubation.

Gelatin liquefaction. Nutrient gelatin containing $10 \%(\mathrm{v} / \mathrm{v})$ horse serum was used. Incubation was at $37^{\circ}$ and was, when necessary, prolonged for 2 weeks.

Casein hydrolysis. Organisms were grown on serum agar plates containing $10 \%$ $(\mathrm{v} / \mathrm{v})$ skim milk. A positive reaction was indicated by clear zones around the colonies after incubation for 2-3 days.

Fibrinolysis. Ten $\%(\mathrm{v} / \mathrm{v})$ fresh human plasma was added to melted nutrient agar and the fibrinogen precipitated at $56^{\circ}$ (Christie \& Wilson, 1941). Plates were poured, dried and inoculated. Clear zones around colonies after 2-3 days of incubation indicated fibrinolysin production.

Litmus milk. Ordinary litmus milk was an unsatisfactory growth medium; $10 \%$ $(\mathrm{v} / \mathrm{v})$ horse serum was incorporated and culture incubated up to 3 weeks.

Amino acid breakdown and sodium malonate utilization. Decarboxylation of lysine, deamination of phenylalanine and utilization of sodium malonate were investigated by micro-methods (Shaw \& Clarke, 1955). Positive and negative controls were included with all tests.

Haemolysis on blood agar. Ten $\%(\mathrm{v} / \mathrm{v})$ of whole blood was added to Lemco nutrient agar. Layered plates were poured and incubated, after inoculation, under optimal growth conditions. Horse, human, sheep, rabbit and chicken blood was used. Evidence of haemolysis was sought after 24 and $48 \mathrm{hr}$.

Haemagglutination. A loopful of a heavy bacterial suspension in saline was added to a drop of $10 \%(\mathrm{v} / \mathrm{v})$ washed red cell suspension on a slide, and rocked gently for 2-3 min. Human group $O$ and chicken red cells were used; the test was done at room temperature and at $4^{\circ}$.

Sodium chloride tolerance. Sodium chloride was incorporated in serum agar in the following concentrations $(\%, \mathrm{w} / \mathrm{v}): 5 \cdot 5,4 \cdot 5,3 \cdot 5,2 \cdot 5,1 \cdot 5,0 \cdot 5$. Plates were inoculated with a drop of a dilute bacterial suspension, sufficient to give semi-confluent growth on control plates, i.e. those containing $0.5 \% \mathrm{NaCl}$. Readings were taken after 3-4 days of incubation. 
Heat resistance. Heavy bacterial suspensions in peptone water were placed in small screw-capped bottles and immersed in water baths at $56^{\circ}$ and $100^{\circ}$. At intervals a large loopful was removed and plated on blood agar.

Viability. Survival at $37^{\circ}$, at room temperature (about $18^{\circ}$ ) and at $4^{\circ}$ was determined by storing fully grown blood agar cultures at these temperatures, and subculturing at intervals to fresh blood agar plates.

Resistance to inhibitory agents. The effect of potassium tellurite, sodium azide, thallous acetate, crystal violet and zinc sulphate was examined by incorporating these substances in blood agar. A drop of bacterial suspension sufficient to give semi-confluent growth on control plates was used as inoculum. Results were read after 3-4 days of incubation. The effect of bile salts was determined by incubation for 4 days on MacConkey agar plates prepared as described in the Ministry of Health Report on the Bacteriological Examination of Water Supplies (1940).

Antibiotics and chemotherapeutic agents. With the exception of polymyxin, all tests were done by the disc method on blood agar plates. Commercially available discs were used. Results were recorded after 2 days of incubation.

\section{Antigenic structure}

Antisera were prepared in rabbits against selected strains. Suspensions of the organisms in formol saline (physiological saline containing $0.5 \%(v / v)$ formalin) were made up to a density of about 3000 million organisms/ml. and injected in $1 \mathrm{ml}$. doses according to a scheme described by Boyd (1947). The animals were bled one week after completion of the course. Sera taken before beginning the injections were shown to contain no agglutinins against the immunizing organisms.

Absorbed sera were prepared by incubation for 3-4 $\mathrm{hr}$ at $52^{\circ}$ with a dense boiled suspension of heterologous organisms. The procedure was repeated when necessary until all agglutinins against the absorbing organisms were removed.

Agglutination tests were done in Dreyer's tubes in a $52^{\circ}$ water bath with suspensions containing about 300 million organisms $/ \mathrm{ml}$. heated at $100^{\circ}$ for $15 \mathrm{~min}$.

Gel precipitation studies were performed by the double diffusion method in plates of Noble (Difco) agar. Dense formol saline suspensions of organisms were used as antigens. Lines of precipitate were allowed to develop for 4 days at $4^{\circ}$.

\section{RESUL'TS}

Moore's findings on the importance of the conjunctiva as a portal of infection in guinea-pig salmonellosis (Moore, 1957) prompted an investigation of the conjunctival flora during an outbreak of pseudotuberculosis in the guinea-pig stock of this laboratory. The eyes of twelve healthy guinea pigs, chosen at random, were swabbed and the swabs inoculated immediately on to $5 \%(\mathrm{v} / \mathrm{v})$ horse blood nutrient agar plates which were incubated in air at $37^{\circ}$. A single swab was used for both eyes. On examination after $48 \mathrm{hr}$ incubation, four of the twelve plates showed a moderately heavy growth of an organism which, on the basis of morphology, colonial appearance, penicillin sensitivity and positive oxidase reaction, was tentatively identified as a Moraxella. A further twelve guinea pigs were then examined in a similar manner immediately on arrival from the supplier and before addition to the stock. Nine of the twelve yielded the same organisms and three of these isolates 
were retained for more complete examination ( 1, E2, E 3). Two other unrelated guinea-pig colonies were then investigated, one in Leicester and one in Somerset. A presumptive Moraxella was isolated from four of twelve animals of the Leicester stock (L1, L2, L3, L4) and from one of twelve of the Somerset stock (T1).

\section{Morphology and colonial appearance}

All the guinea-pig strains were stout Gram-negative, non-motile, non-sporing bacilli with thin capsules. Most cultures tended towards pleomorphism, with swollen forms and filaments, but the general appearance was that of short plump bacilli arranged singly, in end-to-end pairs and in clumps. Neisseria-like forms were seen, especially in some strains. The known stock strains presented an essentially similar appearance but capsules were more prominent in Moraxella bovis and absent from one strain of $\boldsymbol{M}$. liquefaciens (A.183).

After incubation for $24 \mathrm{hr}$ at $37^{\circ}$ on blood agar or serum agar in a candle jar, the guinea-pig strains all gave colonies about $1 \mathrm{~mm}$. diam., round and convex with a smooth surface and translucent greyish appearance. In $48 \mathrm{hr}$ the colonies were larger, up to $3 \mathrm{~mm}$. diam., with a convex centre and a flattened periphery. The colony was friable and not readily emulsifiable. Each colony lay in a shallow pit of digested agar. This property of pitting the agar surface, although very characteristic of freshly isolated strains, was readily lost on subculture.

Under the same conditions Moraxella lacunata of the stock strains gave in $24 \mathrm{hr}$ very small pin-point colonies which increased to a diameter of about $1.5 \mathrm{~mm}$. in 48-72 $\mathrm{hr}$ when they presented a round, convex, greyish translucent appearance with a smooth surface. The colony was friable and very difficult to emulsify. There was no pitting of the agar. One strain of $M$. liquefaciens (A.183) gave colonies very similar to $M$. lacunata, but the growth of the other two resembled that of the guinea-pig strains and one (54.13) caused typical pitting of the agar surface. Moraxella bovis was characterized by rather large, somewhat mucoid, easily emulsifiable colonies, greyish and translucent with a smooth convex glistening surface, about $2 \mathrm{~mm}$. diam. in $24 \mathrm{hr}$, increasing to $4-5 \mathrm{~mm}$. in $48 \mathrm{hr}$. No pitting of the agar was apparent.

\section{Physiological observations}

Growth in liquid media. In liquid media all the guinea-pig strains gave a slight to moderate finely granular turbidity with a moderate flocculent deposit and sometimes a slight ring formation at the surface. Of the stock strains, Moraxella lacunata gave a rather granular deposit with clear supernatant fluid, and no surface growth. One strain of $\boldsymbol{M}$. liquefaciens (A.183) gave a growth similar to $\boldsymbol{M}$. lacunata, while the other two resembled the guinea-pig strains. Moraxella bovis gave a slight to moderate uniform turbidity and powdery deposit with no surface growth.

Optimum atmospheric conditions, temperature and $p H$ value. All strains, guineapig and stock cultures, behaved alike. All were obligate aerobes, no growth occurring under strictly anaerobic conditions. Growth in a candle-jar, however, was rather better than that in air.

The optimum temperature was $37^{\circ}$; growth at $30^{\circ}$ was slower and poorer and at $\mathbf{2 5}^{\circ}$ was very poor or absent.

The optimum $\mathrm{pH}$ range was between 7 and $8 \cdot 5$. No growth occurred at $\mathrm{pH} 6$, was 
poor at $\mathrm{pH} 6.5$ and very poor at $\mathrm{pH}$ 10. All strains were thus much more tolerant of alkaline than of acid conditions.

Nutritional requirements. None of the guinea-pig strains grew in Koser's citrate or Audureau's defined medium. Simple peptone and Lemco media supported the growth of all strains through at least six serial subcultures from small inocula, and the addition of $\mathbf{X}$ and $\mathbf{V}$ factors was without effect. Growth was greatly improved by $10 \%(\mathrm{v} / \mathrm{v})$ horse serum or horse blood. Chocolate agar had no advantage over

\section{Table 1. Biochemical reactions of Moraxella}

\begin{tabular}{|c|c|c|c|c|c|c|c|c|c|c|c|c|c|}
\hline \multirow[b]{3}{*}{ Test } & \multicolumn{13}{|c|}{ Moraxella strains } \\
\hline & \multirow{2}{*}{$\begin{array}{c}M . \\
\text { lacunata } \\
\mathbf{7 9 8 6}\end{array}$} & \multirow{2}{*}{$\begin{array}{l}M . \\
\text { bovis } \\
8561\end{array}$} & \multicolumn{3}{|c|}{ M. liquefaciens } & \multicolumn{8}{|c|}{ Guinea-pig isolates } \\
\hline & & & A. 183 & 54.13 & 7911 & T 1 & E 1 & $\mathbf{E} 2$ & E3 & $\mathbf{L} 1$ & L 2 & L3 & L4 \\
\hline Oxidase & + & + & + & + & + & + & + & + & + & + & + & + & + \\
\hline Catalase & + & + & + & + & + & + & + & + & + & + & + & + & + \\
\hline Nitrate reduction & + & + & + & + & + & + & + & + & + & + & + & + & + \\
\hline Phosphatase & - & - & - & - & - & - & - & - & - & - & - & - & - \\
\hline Urease & - & - & - & - & - & - & - & - & - & - & - & - & - \\
\hline Indole & - & - & - & - & - & - & - & - & - & - & - & - & - \\
\hline Lysine decarboxylase & - & - & - & - & - & - & - & - & - & - & - & - & - \\
\hline $\begin{array}{l}\text { Phenylalanine } \\
\text { deaminase }\end{array}$ & - & - & - & - & - & - & - & - & - & - & - & - & - \\
\hline Malonate & - & - & - & - & - & - & - & - & - & - & - & - & - \\
\hline Serum liquefaction & + & + & + & + & + & + & + & + & + & + & + & + & + \\
\hline Gelatin liquefaction & + & + & + & + & + & + & + & + & + & + & + & + & + \\
\hline Casein digestion & + & + & + & + & + & + & + & + & + & + & + & + & + \\
\hline Litmus milk & - & D & - & D & D & $\mathbf{D}$ & D & D & $\mathbf{D}$ & D & D & D & D \\
\hline Egg-yolk opacity & - & - & - & - & - & \pm & \pm & \pm & \pm & \pm & \pm & \pm & \pm \\
\hline Fibrinolysin & - & \pm & - & - & - & \pm & \pm & \pm & \pm & \pm & \pm & \pm & \pm \\
\hline Acid from carbohydrate & es - & $\overline{-}$ & - & - & - & $\overrightarrow{-}$ & - & - & - & - & $=$ & - & - \\
\hline
\end{tabular}

$+=$ positive result. $\pm=$ weak positive result. $-=$ negative result. $D=$ digestion.

blood agar. Moraxella lacunata and M. liquefaciens A. 183, required media enriched with blood or serum for growth. All other stock cultures resembled the guinea-pig strains in growth requirements.

Action on carbohydrates. None of the strains produced either acid or gas from any of the following substrates: glucose, galactose, arabinose, xylose, rhamnose, sucrose, maltose, lactose, raffinose, inulin, salicin, mannitol, dulcitol, sorbitol, adonitol, erythritol, inositol.

Other biochemical reactions. The results of these tests are shown in Table 1. All strains gave positive results in oxidase, catalase and nitrate reduction tests, but negative reactions in phosphatase, urease, indole, lysine decarboxylase, phenylalanine deaminase and malonate utilization tests. All liquefied coagulated serum rapidly and gelatin more slowly, and digested casein in milk serum agar. Serum litmus milk was decolorized, precipitated and digested by all strains except Moraxella lacunata and $M$. liquefaciens A. 183, both of which gave doubtful growth and produced no change in the medium.

All the guinea-pig isolates produced an opacity on egg-yolk agar confined to the area immediately below the colony; none of the stock strains showed any effect. 
All the guinea-pig strains and Moraxella bovis showed weak fibrinolytic activity, but all other cultures were negative under the conditions of the test.

Haemolysis on blood agar. Moraxella bovis was the only organism which produced zones of clear haemolysis on blood agar media. The best zones were obtained with horse blood but human, chicken and sheep red cells were also lysed; there was no effect on rabbit red cells. None of the other strains gave clear haemolytic zones with any of the red cells tested, but greening of the medium commonly occurred. No attempt was made to show soluble haemolysin.

Haemagglutination. One strain of Moraxella liquefaciens (54.13) agglutinated human and chicken red cells, at room temperature and at $4^{\circ}$. All other strains, whether from guinea-pig or from stock, did not.

Sodium chloride tolerance. Moraxella lacunata and one strain of M. liquefaciens (A. 183) did not grow at sodium chloride concentrations higher than $1.5 \%(\mathrm{w} / \mathrm{v})$. All the other cultures gave adequate growth at $2 \cdot 5 \%(\mathrm{w} / \mathrm{v})$ but were completely in hibited at $\mathbf{3 \cdot 5} \%(\mathrm{w} / \mathrm{v})$ or greater (Table 2$)$.

Inhibitory agents. The effect of various agents on growth is shown in Table 2. None of the strains grew in the presence of potassium tellurite or sodium azide at the concentrations tested. Thallous acetate at 1/8000 suppressed all growth, but minimal growth of the guinea-pig strains occurred at 1/16,000. All strains were inhibited by $1 / 250,000$ crystal violet; $M$. lacunata, $M$. bovis and a single strain of $M$. liquefaciens (A. 183) were also suppressed by $1 / 500,000$ of this dye, but all other organisms gave moderate growth at this level.

Zinc sulphate sensitivity tests were performed, since this substance has been successfully used in the treatment of moraxella conjunctivitis; Moraxella lacunata and $M$. bovis grew at $1 / 80,000$ but not at $1 / 70,000$; all other strains grew at $1 / 60,000$ to $1 / 50,000$ but not at higher concentrations. For comparison the zinc sulphate sensitivity of organisms of several genera other than Moraxella was also examined. Strains of Escherichia coli (1), Klebsiella aerogenes (1), Shigella sonnei (1), Salmonella typhimurium (1), Pseudomonas aeruginosa (1), Brucella abortus (1) and Chromobacter sp. (2) proved highly resistant to zinc sulphate, growing at a 1/5000 concentration. Strains of Pasteurella septica (1) Haemophilus influenzae (1) Neisseria meningitidis (1) and 2 Neisseria sp. from the human upper respiratory tract gave results similar to the Moraxellas. Thus, although sensitivity to zinc sulphate appears to be characteristic of Moraxella, it cannot be used as a ready means of identification.

No strains grew on MacConkey agar.

Antibiotics and chemotherapeutic agents. All the guinea-pig strains and all the stock strains were sensitive to penicillin, novobiocin, chloramphenicol, tetracycline, streptomycin, neomycin, nitrofurantoin and nitrofurazone. All gave poor growth in the presence of 5 units polymyxin $\mathrm{B} / \mathrm{ml}$. and were inhibited completely by 10 units. All strains were resistant to bacitracin with the exception of Moraxella lacunata, $M$. bovis and $M$. liquefaciens A. 183. All the guinea-pig strains and one strain of $M$. liquefaciens (7911) were either resistant or only slightly sensitive to erythromycin; the other strains were sensitive.

Heat resistance. All strains were killed in less than one minute at $100^{\circ}$. Moraxella lacunata, M. bovis and M. liquefaciens A. 183, were killed in 5 min. at 56 ${ }^{\circ}$. All other strains survived at $56^{\circ}$ for 15 but not for $30 \mathrm{~min}$. 
Viability. Moraxella lacunata and M. liquefaciens A. 183, survived 2 days at room temperature (about $\mathbf{1 8}^{\circ}$ ) but subcultures on the third day gave no growth. All other strains survived 7 days at room temperature but not 10 days. At $37^{\circ}$ in a candle jar all strains were still viable at the end of 2 weeks, when the test was discontinued. At $4^{\circ}, M$. lacunata and $M$. liquefaciens A. 183, survived 2 but not 3 weeks while all others were still alive at the end of 4 weeks when the test was discontinued.

\section{Antigenic structure}

Smooth suspensions for agglutination were most readily obtained by boiling, combined, when necessary, with vigorous shaking with glass beads. Formolized suspensions were more unstable, and, since preliminary tests showed little difference in reaction, it was decided to use boiled suspensions throughout. Agglutination tests were not possible with Moraxella liquefaciens A. 183, because stable suspensions could not be prepared; this strain is thus excluded from the results. Agglutination at $52^{\circ}$ was of granular type and became evident in $2-4 \mathrm{hr}$ although higher titres were obtained after overnight incubation. All titres recorded below refer to overnight readings.

Table 3. Agglutination reactions of guinea-pig strains of Moraxella

\begin{tabular}{|c|c|c|c|c|c|c|c|c|}
\hline \multirow[b]{2}{*}{ Antisera } & \multicolumn{8}{|c|}{ Antigens (isolate reference code) } \\
\hline & T 1 & $\mathbf{E} \mathbf{1}$ & $\mathrm{E} 2$ & $\mathbf{E} 3$ & $\mathbf{L} 1$ & $\mathbf{L} 2$ & L3 & $\mathbf{L 4}$ \\
\hline $\begin{array}{c}\text { T1 antiserum } \\
\text { (unabsorbed) }\end{array}$ & 2500 & 2500 & 1000 & 1000 & 250 & $\mathbf{2 5 0}$ & 1000 & 500 \\
\hline $\begin{array}{l}\text { L1 antiserum } \\
\text { (unabsorbed) }\end{array}$ & 250 & 250 & 125 & 125 & 1500 & 1000 & 1000 & 1000 \\
\hline $\begin{array}{l}\text { T } 1 \text { antiserum (absorbed } \\
\text { with } \mathrm{L} 1 \text { antigen) }\end{array}$ & 250 & 500 & 250 & 500 & $\mathbf{0}$ & $\mathbf{0}$ & $\mathbf{0}$ & 0 \\
\hline $\begin{array}{l}\text { L1 antiserum (absorbed } \\
\text { with } \mathbf{T} 1 \text { antigen) }\end{array}$ & 0 & 0 & 0 & 0 & 0 & 0 & 0 & 0 \\
\hline
\end{tabular}

Figures represent reciprocals of the dilutions; $0=$ no agglutination. The lowest dilution of serum tested was $1 / 50$.

Antisera were prepared against two guinea-pig strains $(\mathrm{T} 1, \mathrm{~L} \mathbf{1})$ and against one stock strain of Moraxella liquefaciens 54.13. All sera agglutinated the homologous antigens to high titre and the $\mathbf{5 4 . 1 3}$ antiserum reacted with no other. The T1 and L1 antisera each agglutinated all guinea-pig cultures but none of the others. The guineapig organisms appeared to fall into two antigenic groups. Thus strains E 1, E2, E3 and $\mathrm{Tl}$ reacted to a higher titre with $\mathrm{T} 1$ antiserum than with $\mathrm{L} 1$ antiserum, while strains L1, L2, L3 and L4 gave the reverse. Absorption of L1 antiserum with T1 suspension removed agglutinins to all the guinea-pig strains, but absorption of $\mathrm{T} 1$ antiserum with $\mathrm{L} 1$ organisms removed completely only agglutinins against the $\mathrm{L}$ group. It thus appeared that the $\mathbf{E}-\mathbf{T}$ group possessed at least two major antigens, one of which was also present in the $\mathrm{L}$ group.

Gel-diffusion tests confirmed this finding. T1 antiserum gave only one line of precipitate against $\mathrm{L}$ group antigens but two lines against $\mathbf{E}-\mathbf{T}$ suspensions, whereas L1 antiserum gave only one precipitate-line in either case. Gel diffusion revealed no antigenic relationship between the guinea-pig and the stock strains; the antiserum 
against Moraxella liquefaciens $\mathbf{5 4 . 1 3}$ reacted only with homologous antigens. Agglutination test results are summarized in Table 3.

\section{Pathogenicity}

Serum broth cultures $(48 \mathrm{hr}$ ) of guinea-pig strains $\mathrm{T} 1$ and $\mathrm{L} 1$ were tested in adult mice and guinea pigs. Each strain was inoculated intraperitoneally into a mouse in a dose of $0.5 \mathrm{ml}$. culture, and one drop of culture was instilled into each eye of a guinea pig, the cornea of one eye being previously scarified with a needle. All the animals remained healthy and no lesions were detectable. It must be noted, however, that previous exposure could not be excluded as the guinea-pig stock was known to be infected and the laboratory mice were housed in the same quarters. Sera of the stock animals were not tested for the presence of agglutinins. The principal reactions of all strains are summarized in Table 4. It is noteworthy that strain A. 183, received as a rough culture of Moraxella liquefaciens, gave the reactions of M. lacunata.

Table 4. Principal reactions of guinea-pig and stock Moraxella strains

All strains were strict aerobes, of optimum temperature for growth $37^{\circ}$ and $\mathrm{pH}$ range 6.5-10.

\begin{tabular}{|c|c|c|c|c|c|c|c|c|c|c|c|c|c|}
\hline & \multicolumn{13}{|c|}{ Moraxella strains } \\
\hline & \multirow{2}{*}{$\begin{array}{c}M . \\
\text { lacu- } \\
\text { nata } \\
7986\end{array}$} & \multirow{2}{*}{$\begin{array}{c}\text { M. } \\
\text { bovis } \\
8561\end{array}$} & \multicolumn{3}{|c|}{ M. liquefaciens } & \multicolumn{8}{|c|}{ Guinea-pig isolates } \\
\hline & & & A. 183 & 54.13 & 7911 & T 1 & $\mathbf{E} 1$ & $\mathbf{E 2}$ & $\mathbf{E} 3$ & $\mathbf{L} \mathbf{1}$ & $\mathbf{L 2}$ & $\mathbf{L} \mathbf{3}$ & L4. \\
\hline \multicolumn{14}{|c|}{ (2) } \\
\hline Defined medium & - & - & - & - & - & - & - & - & - & - & - & - & - \\
\hline Peptone water media & - & + & - & + & + & + & + & + & + & + & + & + & + \\
\hline Enriched media & + & + & + & + & + & + & + & + & + & + & + & + & + \\
\hline Acid from carbohydrates & - & - & - & - & - & - & - & - & - & - & - & - & - \\
\hline $\begin{array}{l}\text { Liquefaction of coagu- } \\
\text { lated serum }\end{array}$ & + & + & + & + & + & + & + & + & + & + & + & + & + \\
\hline Hydrolysis of casein & + & + & + & + & + & + & + & + & + & + & + & + & + \\
\hline Indole production & - & - & - & - & - & - & - & - & - & - & - & - & - \\
\hline Nitrate reduction & + & + & + & + & + & + & + & + & + & + & + & + & + \\
\hline Oxidase & + & + & + & + & + & + & + & + & + & + & + & + & + \\
\hline Catalase & + & + & + & + & + & + & + & + & + & + & + & + & + \\
\hline Urease & - & - & - & - & - & - & - & - & - & - & - & - & - \\
\hline Phosphatase & - & - & - & - & - & - & - & - & - & - & - & - & - \\
\hline Haemolysin production & - & + & - & - & - & - & - & - & - & - & - & - & - \\
\hline \multicolumn{14}{|c|}{ Growth in sodium chloride } \\
\hline $\mathbf{3 . 5} \%$ & - & - & - & - & - & - & - & - & - & - & - & - & - \\
\hline $2.5 \%$ & - & + & - & + & + & + & + & + & + & + & + & + & + \\
\hline $1.5 \%$ & + & + & + & + & + & + & + & + & + & + & + & + & + \\
\hline Penicillin & $\mathbf{S}$ & $\mathbf{S}$ & $\mathbf{S}$ & $\mathbf{S}$ & $\mathbf{S}$ & $\mathbf{S}$ & $\mathbf{S}$ & $\mathbf{S}$ & $\mathbf{S}$ & $\mathbf{S}$ & $\mathbf{S}$ & $\mathbf{S}$ & $\mathbf{S}$ \\
\hline Zinc sulphate & $\mathbf{S}$ & $\mathbf{S}$ & $\mathbf{S}$ & $\mathbf{S}$ & $\mathbf{S}$ & $\mathbf{S}$ & $\mathbf{S}$ & $\mathbf{S}$ & $\mathbf{S}$ & $\mathbf{S}$ & $\mathbf{S}$ & $\mathbf{S}$ & $\mathbf{S}$ \\
\hline
\end{tabular}

\section{DISCUSSION}

Lwoff (1939) divided the genus Moraxella into two groups according to growth requirements, i.e. a group requiring enriched media and one growing on simple peptone water media. Petit's bacillus, now designated $M$. liquefaciens, was in the latter subdivision. Audureau (1940) showed the failure of these organisms to grow 
on simple defined media. Henriksen (1952) drew attention to the resemblance of members of the genus to Neisseria as evidenced by a tendency to coccoid or diplococcoid morphology, ready occurrence of involution forms, positive oxidase reaction and sensitivity to penicillin. The morphological and cultural characters of our guinea-pig isolates qualify them for inclusion in the genus Moraxella, and their conjunctival habitat is perhaps not without significance in this respect. According to the criteria of Lwoff and of Audureau, the growth requirements would identify our isolates as $M$. liquefaciens, and they do indeed conform in every way to the essential characteristics of this species. Although no antigenic relationship was demonstrable between the guinea-pig strains and the available stock strains of $M$. liquefaciens, it is also true that the latter apparently differ amongst themselves. Little is known about the antigenic structure of Moraxella. Chaine (1914) and Scarlett $(1961 b)$ did not detect any relationship between the Morax-Axenfeld bacillus and Petit's bacillus. These authors, however, only used single strains. Each species may well be antigenically heterogeneous. The guinea-pig strains appear to form two antigenic types of a single group. Present information is not sufficient to assess the significance of this finding in relation to human strains.

The strain of Moraxella bovis examined, although conforming in cultural requirements to $\boldsymbol{M}$. liquefaciens, was readily distinguishable from that organism and from the guinea-pig isolates by its characteristic haemolysis, the formation of large semimucoid colonies, and the smooth nature of the growth on solid and in liquid media.

The creation of a new species such as Moraxella caviae, or even a new variety, $M$. liquefaciens var. caviae, to accommodate the guinea-pig organisms does not seem justifiable. It would seem more reasonable, at present, to regard them as strains of $M$. liquefaciens isolated from guinea-pig conjunctiva. If the guinea-pig strains are identifiable as $\boldsymbol{M}$. liquefaciens, the question of their relationship to human disease arises. Petit's bacillus is held to be an uncommon organism. It is usually associated with corneal ulceration but has also been isolated from cases of systemic infection, especially in the tropics (Faucon, Saboret, Dodin \& Rajaonera, 1961). The dealer who supplied the original guinea pigs had no history of ophthalmic disease or other illness. Moreover, the isolation of Moraxella from three separate guinea-pig stocks seems to indicate that these animals are normal hosts. To determine whether rodents in closer contact with the general human population might also be infected, a series of thirteen wild house-mice were examined by conjunctival swabbing. The mice were examined within a few hours of being killed but no Moraxella was found. However, all swabs yielded large numbers of mixed organisms and the presence of Moraxella in small numbers might well have been obscured. In any event, the possibility of transfer of infection to man from an animal reservoir seems worthy of consideration.

Strains L1 and El have been deposited with the National Collection of Type Cultures, Colindale. Their reference numbers are respectively NCTC 10358 and NCTC 10359.

I am indebted to Dr S. Cowan for freeze-dried cultures of Moraxella from the National Collection of Type Cultures, Colindale, London, and to Dr M. Piéchaud for similar strains from the Institut Pasteur, Paris. I am also indebted to Dr B. Moore, Public Health Laboratory, Exeter, for criticism of the text. 


\section{REFERENCES}

Audureau, A. (1940). Etude du genre Moraxella. Annls Inst. Pasteur, Paris, 64, 126.

Barber, M. \& KuPER, S. W. A. (1951). Identification of Staphylococcus pyogenes by the phosphatase reaction. J. Path. Bact. 63, 65.

BoYD, W. C. (1947). Fundamentals of Immunology, 2nd ed. p. 402. London: Interscience Publishers Ltd.

Chaine, R. (1914). Différenciation du Diplobacille de Morax et du Diplobacille de Petit à l'aide des réactions biologiques. Annls Oculist. 152, 330.

Christensen, W. B. (1946). Urea decomposition as a means of differentiating Proteus and paracolon cultures from each other and from Salmonella and Shigella types. J. Bact. 52, 461.

Christie, R. \& Wilson, H. (1941). A test of staphylococcal fibrinolysis. Aust. J. exp. Biol. med. Sci. 19, 329.

Cook, G. T. (1950). A plate test for nitrate reduction. J. clin. Path. 3, 359.

Duguin, J. P. (1951). The demonstration of bacterial capsules and slime. J. Path. Bact. 63, 673 .

Faucon, R., Saboret, P., Dodin, A. \& Rajaonera, F. (1961). A propos de quatre observations d'affections à Moraxella décelées á Tananarive. Med. trop. 21, 793.

Flamm, H. (1956). Moraxella saccharolytica (sp.n.) aus dem Liquor eines Kindes mit Meningitis. Zbl. Bakt. (1 Abt. Orig.) 166, 498.

GiLlies, R. R. (1960). In Mackie \& McCartney's Handbook of Bacteriology. 10th ed. Ed. by R. Cruickshank, p. 609. Edinburgh and London: Livingstone.

Henriksen, S. D. (1952). Moraxella: Classification and Taxonomy. J. gen. Microbiol. 6, 318.

Henriksen, S. D. (1960). Moraxella: Some problems of taxonomy and nomenclature. Int. Bull. bact. Nomencl. 10, 23.

Jones, F. S. \& LitTle, R. B. (1923). An infectious ophthalmia of cattle. J. exp. Med. 38, 139.

Lwoff, A. (1939). Revision et démembrement des Haemophilae. Le genre Moraxella nov. gen. Annls Inst. Pasteur, Paris, 62, 168.

Moore, B. (1957). Observations pointing to the conjunctiva as the portal of entry in Salmonella infections of guinea-pigs. J. Hyg., Camb. 55, 414.

Piéchaud, D., Piéchaud, M. \& Second, L. (1951). Étude de 26 souches de Moraxella lrooffii. Annls Inst. Pasteur, Paris, 80, 97.

Repont (1940). Rep. Pub. Htth Med. Subj., Min. Hlth London, no. 71. Revised ed., p. 52.

Scarlet, M. (1916a). Infections cornéennes á diplobacilles. Note sur deux diplobacilles non encore décrit. Annls Oculist. 153, 100.

ScarletT, M. (1916b). Différenciation des variétés de diplobacilles par les réactions humorales. Annls Oculist. 153, 485.

Schaub, I. \& Hauber, F. D. (1948). A biochemical and serological study of a group of identical unidentifiable Gram-negative bacilli from human sources. J. Bact. 56, 379.

Shaw, C. \& Clarke, P. H. (1955). Biochemical classification of Proteus and Providence cultures. J. gen. Microbiol. 13, 155.

Stokes, E. J. (1960). Clinical Bacteriology, 2nd ed., p. 290. London: Arnold.

Watson, K. C. \& Bennetr, M. A. E. (1957). Gradient-type hydrogen ion concentration plates. J. Lab. clin. Med. 50, 639. 